TAPROBANICA, ISSN 1800-427X. January, 2015. Vol. 07, No. 01: pp. 54-55.

(C) Research Center for Climate Change, University of Indonesia, Depok, Indonesia \& Taprobanica Private Limited, Homagama, Sri Lanka

www.taprobanica.org

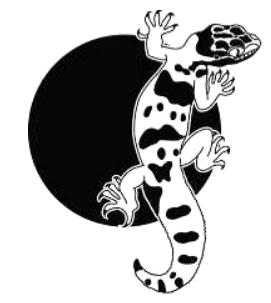

\section{Sarus Crane (Grus antigone) egg is hatched by a domestic hen}

Nehru Zoological Park, Hyderabad, Telangana, India, has been involved in captive breeding programmes, including eggs of silver pheasant (Lophura nycthemera), red jungle fowl (Gallus gallus), kalij pheasant (Lophura leucomelanos) and golden pheasant (Chrysolophus pictus) incubated by domestic hen (Gallus gallus domesticus). It proved successful in almost all cases. Here, we attempted to do the same for the sarus crane (Grus antigone), which is listed in Schedule I of the Wildlife (Protection) Act 1972, vulnerable species on IUCN Red List 2012, Appendix II of CITES, and Appendix II of the Convention on Migratory Species. It is the largest bird in India and the tallest flying bird in the world (Sundar et al., 2000; Sundar \& Choudhury 2003; Sundar, 2009).

On 10 August 2013, a captive sarus crane laid three eggs in its enclosure. One egg was collected and placed inside the enclosure of a domestic hen. The remaining two eggs were incubated by parent sarus cranes and were hatched after 31 days (on 10 September). The domestic hen also incubated the egg of the sarus crane and it hatched after 32 days (On 11 September). The chick was hand fed from 12 September onwards. Initially, wheat, jowar and ground nut with mineral mixture were given. From 15-23 September, boiled fish mixed with mineral mixture was given. From 24 September onwards, grass hoppers, calcium powder, and mineral mixture were give. Spines and skeleton in the food stuffs were carefully avoided. Zoo veterinary doctors and zoo keepers periodically monitored the growth, weight, and health of the sarus chick three times every day (10:30, 14:30, and 19:30 hr). While monitoring the chick, the hen was moved in to a small cage to avoid disturbance. Food was provided three times per day: 11:00, 15:00, and 18:00 hr. The height and weight of the chick were measured respectively in four different times: 2-day old hatchling: 4.2 $\mathrm{cm}, 30 \mathrm{~g}$; 15-day old nestling: $11.2 \mathrm{~cm}, 300 \mathrm{~g}$; 45-day old fledgling: $75 \mathrm{~cm}, 3.2 \mathrm{~kg}$; and $140-$ day old adult $180 \mathrm{~cm}, 7.9 \mathrm{~kg}$.

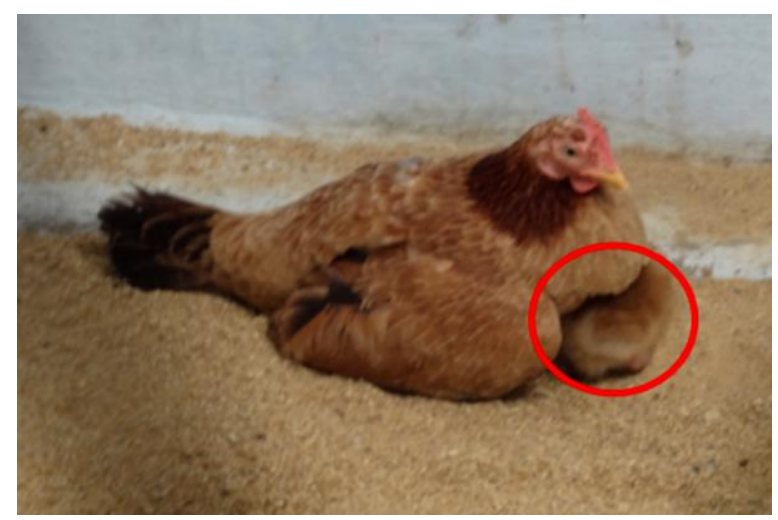

Figure 1: Parental care by domestic hen (crane chick in the red circle).

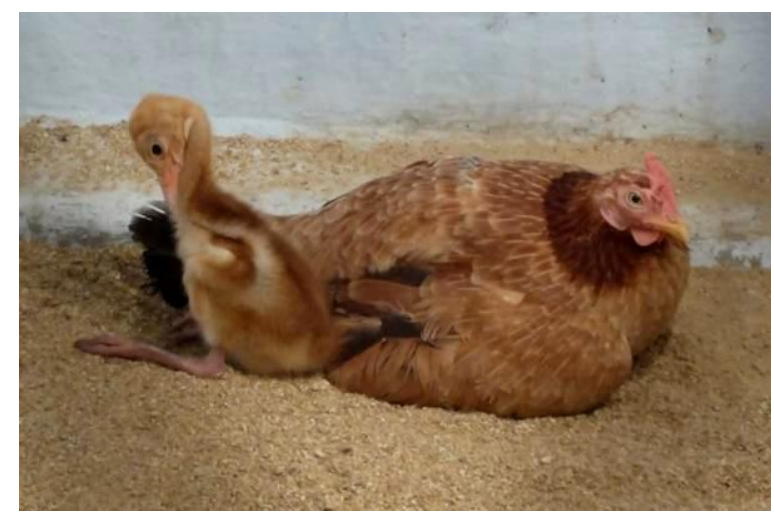

Figure 2: Active crane chick and domestic hen.

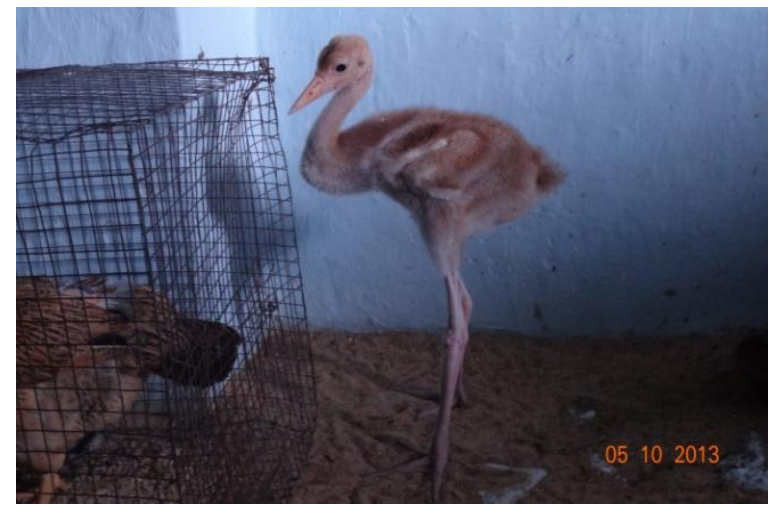

Figure 3: 25-day old crane chick and domestic hen. 


\section{Acknowledgement}

We express our sincere thanks to Sri Mallikarjuna Rao (Director) and Sri Shakaran (Curator) at Nehru Zoological Park, Hyderabad, for their encouragement and support during the manuscript preparation.

\section{Literature Cited}

IUCN, 2012. IUCN Red List of Threatened Species (2012:1). Downloaded at <www.iucnredlist.org> on 19 June 2012.

Sundar, K. S. G., 2009. Are rice paddies suboptimal breeding habitat for Sarus Cranes in Uttar Pradesh, India? Condor, 111: 611-623.

Sundar, K. S. G. and B. C. Choudhury, 2003. The Indian Sarus Crane Grus antigone: a literature review. Journal of Ecological Society, 16: 16-41.

Sundar, K. S. G., J. Kaur, and B. C. Choudhury, 2000. Distribution, demography and conservation status of the Indian Sarus Crane (Grus antigone antigone) in India. Journal of the Bombay Natural History Society, 97: 319-339.

Submitted: 18 July 2014, Accepted: 14 Oct. 2014 Section Editor: Varadharajan Gokula

M. Sandeep ${ }^{1}$, P. Srinivas ${ }^{1}$, B.L Narayana ${ }^{2} \&$ D. Adimallaiah $^{3}$

${ }^{1}$ Nehru Zoological Park, Hyderabad, Telangana, India

${ }^{2}$ All India Network Project On Agricultural Ornithology, ANGR Agricultural University, Rajendera Nagar, Hyderabad 500030, Telangana, India E-mail: narayana.laxmi8@gmail.com

${ }^{3}$ Wildlife Crime Control Bureau, Southern Region, Chennai, India 